MODERN IRAN 


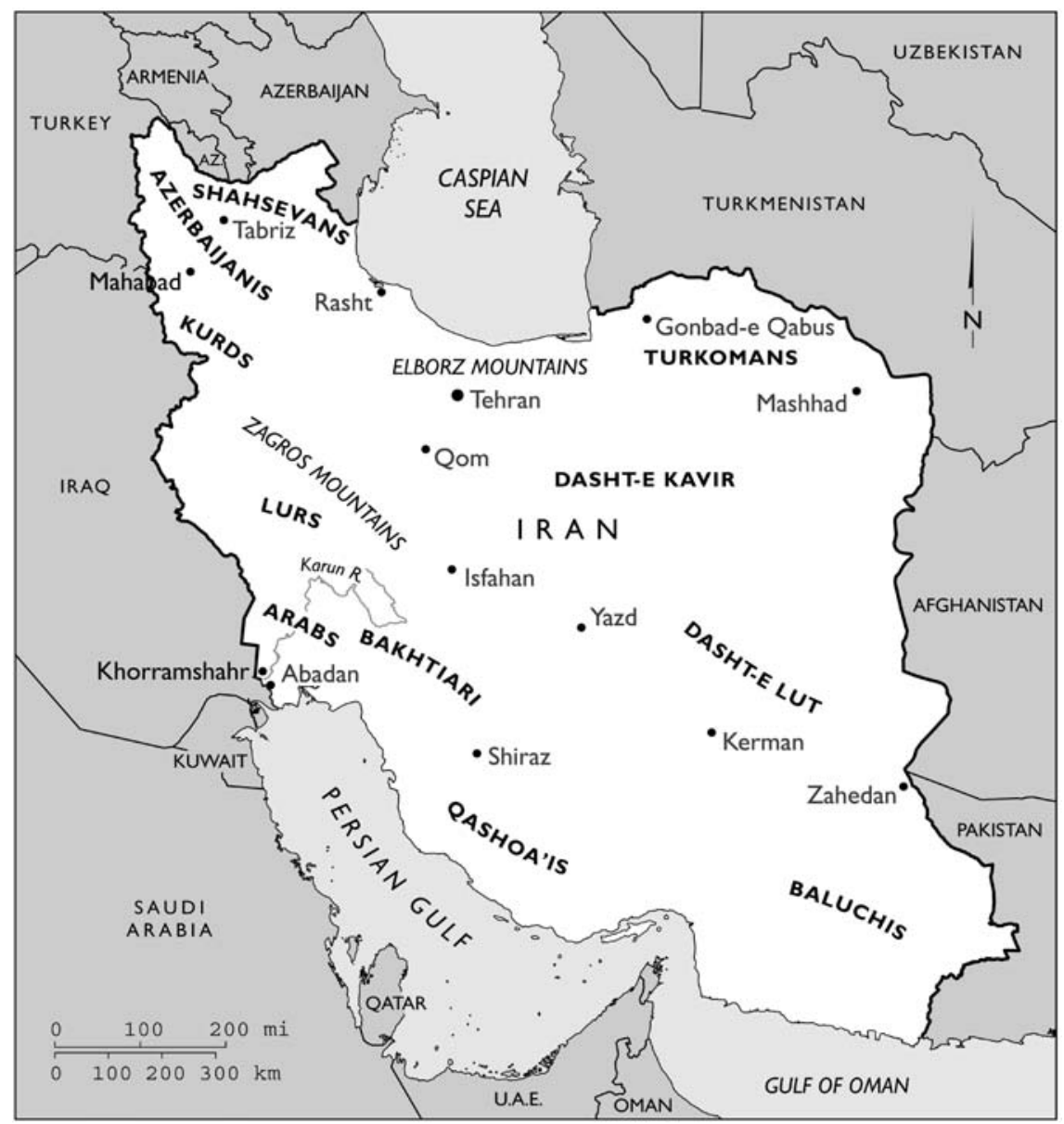




\section{Modern Iran}

Roots and Results of Revolution Updated Edition

\section{Nikki R. Keddie}

with a section by Yann Richard

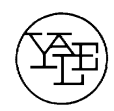

Yale University Press New Haven \& London 
Modern Iran, a substantially revised and expanded version of Roots of Revolution (1981), first published 2003 by Yale University Press. This Updated Edition published 2006 by Yale University Press.

Copyright $\odot$ 2003, 2006 by Yale University.

All rights reserved.

This book may not be reproduced, in whole or in part, including illustrations, in any form (beyond that copying permitted by Sections 107 and 108 of the U.S. Copyright Law and except by reviewers for the public press), without written permission from the publishers.

Designed by James J. Johnson and set in Stemple Garamond type by Keystone Typesetting, Inc.

Printed in the United States of America.

Library of Congress Control Number: 2006923987

ISBN-13: 978-0-300-12105-6 (pbk. : alk. paper)

ISBN-10: 0-300-12105-9 (pbk. : alk. paper)

A catalogue record for this book is available from the British Library.

The paper in this book meets the guidelines for permanence and durability of the Committee on Production Guidelines for Book Longevity of the Council on Library Resources. 


\section{To the people of Iran}

\section{3-A year of major anniversaries}

- 50 years since the coup overthrowing prime minister Mohammad Mosaddeq.

- 25 years since the main events of the 1978-79 revolution.

- 6 years since the landslide election of president Mohammad Khatami.

- The struggle continues

... could thou and I with Fate conspire

To grasp this sorry Scheme of Things entire,

Would not we shatter it to bits-and then

Re-mold it nearer to the Heart's Desire!

An eleventh-century Iranian scientist

Religious distress is at the same time the expression of real distress and also the protest against real distress. Religion is the sigh of the oppressed creature, the heart of a heartless world, just as it is the spirit of spiritless conditions. It is ...

A nineteenth-century European socialist 
This page intentionally left blank 